\title{
The prevalence of feline parasites in Suwon, Korea
}

\author{
Heejeong Youn ${ }^{1, *}$, Myung-Rae Cho ${ }^{1}$, Yong-Suk Lim ${ }^{1}$, Kyoung Hee Kim ${ }^{1}$, Bo-Kyung Bae ${ }^{1}$, \\ Namsik Shin ${ }^{1}$, Ho-Woo Nam ${ }^{2}$ \\ ${ }^{1}$ College of Veterinary Medicine, Seoul National University, Seoul 151-742, Korea \\ ${ }^{2}$ Deoartment of Parasitology and Catholic Institute of Parasitic Diseases, College of Medicine, \\ Catholic University of Korea, Seoul 137-701, Korea \\ (Received: November 14, 2011; Revised: November 15, 2011; Accepted: November 16, 2011)
}

\begin{abstract}
Feline parasites were investigated in the area of Suwon in Korea from September to October, 2003. Wild cat had spread to zoonotic parasites, these parasites could cause infection with a person. People have a lot of interest in parasite infection of wild cat. This article reviews rate of infection of a parasites and kind of a parasite of wild cats. We will report the critical characteristic features of parasites to a better understanding of the disease. The incidence rates of Toxocara cati, Trichuris felis, Ancylostoma braziliense and Capillaria sp were 37.0, 4.3, 1.1 and 1.1\% in nematodes. Those of Taenia taeniaformis and Opisthorchis sp were 2.2 and $1.1 \%$ in cestode and trematode. Those of Isospora felis, Toxoplasma gondii, and Sarcocystis sp were 8.7, 9.8, and 2.2\% in protozoa. Almost of these were zoonotic parasites without Isospora felis.
\end{abstract}

Keywords : feline parasites, Toxocara cati, Toxoplasma gondii, Trichuris felis, wild cats

\section{Introduction}

After the late of 20 century, some associations of animal wealth require not to kill wild animals, especially cats. Therefore, stray cats were increased more and more around our environment. Toxoplasma (T.) gondii is found worldwide and in an exceptionally broad host range and is the zoonotic parasites infected to human. $T$. gondii were reported cats and human infections in Korea by some Korean researchers [2-6, 8, 9, 11, 13$16,19,20,22]$. T. gondii specific immunoglobulins were synthesized by the host in response to infection using serologic tests. Toxocara cati is the most popular nematode and zoonotic parasite in cat in Korea. Some Korean researchers [7, 8, 12, 17, 18] reported the cats and the human infections of Toxocara cati. Toxocara cati has long been considered a parasitic disease affecting pet owners and children. Trichuris felis is also popular nematode in cat in Korea. Infections of Trichuris felis are either asymptomatic or subclinical. Cat becomes infected by ingesting food or water contaminated with Trichuris felis eggs. Taenia taeniaformis is cestode in the cat. It is heterogenetic parasite, its intermediate host is rodents and final host is felidae. Many of these are zoonotic parasites, so that we investigated the infection rates of these parasites in stray cats.

\section{Materials and Methods}

\section{Animal feces and blood}

Feline feces and blood were supplied from animal hospitals in Suwon area from September to October 2003. The stray cats were captured by animal doctors to castrate and the feces and bloods were collected from them.

\section{Fecal examination}

In order to investigate the infections of intestinal parasites, such as nematodes, cestodes and protozoa, all fecal samples were examined by saturated sodium hydrochloride flotation technique. In a $15 \mathrm{~mL}$ centrifuge tube, thoroughly emulsify about $1 \mathrm{~g}$ feces with $3 \sim 5 \mathrm{~mL}$ tap water. Pour through two layers of gauze held in a small funnel inserted into another $15 \mathrm{~mL}$ centrifuge tube,

\footnotetext{
*Corresponding author

Tel: +82-2-880-1267, Fax: +82-2-888-0659

E-mail: younhj@snu.ac.kr
} 
Table 1. Incidence rates of nematodes in wild cats in Suwon area

\begin{tabular}{ccccccc}
\hline \hline Sex & No. cats & Toxocara cati (\%) & $\begin{array}{c}\text { Trichuris felis } \\
(\text { vulpis) }(\%)\end{array}$ & $\begin{array}{c}\text { Ancylostoma } \\
\text { braziliense (\%) }\end{array}$ & Capillaria sp (\%) & Total (\%) \\
\hline Male & 38 & $15(39.5)$ & $1(2.6)$ & - & - & $16(42.1)$ \\
Female & 54 & $19(35.2)$ & $3(5.6)$ & $1(1.9)$ & $1(1.9)$ & $24(44.4)$ \\
Total & 92 & $34(37.0)$ & $4(4.3)$ & $1(1.1)$ & $1(1.1)$ & $40(43.5)$ \\
\hline
\end{tabular}

Table 2. Incidence rates of cestodes and trematode in wild cats in Suwon area

\begin{tabular}{ccccc}
\hline \hline Sex & No. cats & Taenia taeniaformis $(\%)$ & Opisthorchis sp (\%) & Total (\%) \\
\hline Male & 38 & $2(5.3)$ & - & $2(5.3)$ \\
Female & 54 & - & $1(1.9)$ & $1(1.9)$ \\
Total & 92 & $2(2.2)$ & $1(1.1)$ & $3(3.3)$ \\
\hline
\end{tabular}

Table 3. Incidence rates of protozoa in wild cats in Suwon area

\begin{tabular}{cccccc}
\hline \hline Sex & No. cats & Isospora felis $(\%)$ & Toxoplasma gondii $(\%)$ & Sarcocystis sp (\%) & Total (\%) \\
\hline Male & 38 & $2(5.3)$ & $2(5.3)$ & - & $4(10.5)$ \\
Female & 54 & $6(11.1)$ & $7(13.0)$ & $2(3.7)$ & $15(27.8)$ \\
Total & 92 & $8(8.7)$ & $9(9.8)$ & $2(2.2)$ & $19(20.7)$ \\
\hline
\end{tabular}

Centrifuge for $1 \mathrm{~min}$ at 2,000 rpm. Pour supernatant into a bowl containing disinfectant. Sodium hydrochloride fluid is then added to the tube with the feces. After 2 3 min, any parasitic eggs present in the feces will float to the top of the fluid. The top layer of fluid is placed on a microscope slide and examined under a microscope. Flotation solutions with higher densities are capable of floating heavier (denser) parasite stages.

\section{Serological test}

Examination of Blood Protozoa is probably as many different methods of stain (Giemsa's staining). The following has been found to be a rapid method with excellent results. Air-dry smear and fix in absolute methanol (1 min) shake off liquid, but keep we Place smears in stain for $10 \mathrm{~min}$ or place some stain on the slide. Gently rinse in small stream of tap water. Air-dry and observe (add a thin layer of immersion oil). In order to investigate the infections of T. gondii, blood samples were examined by serological test, ELISA. Animals and serum samples - A total of 98 serum samples were obtained from cat (animal hospitals in Suwon area).

T. gondii from blood or body fluids synthesized by the host in response to infection using serological tests - An indirect haemagglutin-ation test (IHA) was performed using a reagent commercially available (Hematoxo, Biolab Diagnostica SA, Brazil). The serum samples were diluted twofold, from $1: 64$ to $1: 2,048$, following the steps described by the manufacturer. All positive serum samples in the IHA test were retested after treatment with 2-Mercaptoethanol in order to verify the presence of IgM antibodies [1]. Other IHA (M-Toxo) developed by Yamamoto et al. [21] for the serodiagnosis of acute toxoplasmosis was carried out with a standardized suspension of red blood cells coated with a heat-stable alkaline-solubilized extract of $T$. gondii, which reacts predominantly with $\mathrm{IgM}$ antibodies. To $50 \mathrm{~mL}$ of doubling diluted serum, as above mentioned, $25 \mathrm{~mL}$ of sensitized cell suspensions were added and the agglutination pattern read after incubation of $1 \mathrm{~h}$ and 30 min at room temperature. Positive and negative reference serum samples (for IgG and IgM specific to $T$. gondii) were included in all assays.

\section{Results}

Incidence rates of nematodes in cats were as follows, those of Toxocara cati $(37.0 \%)$ were higher than those of other nematodes, such as Trichuris felis (vulpis) (4.3\%), Ancylostoma braziliense (1.1\%) and Capillaria sp (1.1\%). That of Toxocara cati $(35.2 \%)$ in male was higher than that in female, but those other nematodes in female were higher than those in male, such as Trichuris felis (vulpis) (5.6\%), Ancylostoma braziliense (1.9\%) and Capillaria sp (1.9\%) (Table 1). Incidence rates of cestodes and trematodes in cats were very low. 
Table 4. Serological diagnosis of Toxoplasma gondii in wild cats in Suwon area by ELISA

\begin{tabular}{cccc}
\hline \hline Sex & No. cats & Toxoplasma gondii $(\%)$ & Total (\%) \\
\hline Male & 38 & $2(5.3)$ & $4(10.5)$ \\
Female & 54 & $7(13.0)$ & $15(27.8)$ \\
Total & 92 & $9(9.8)$ & $19(20.7)$ \\
\hline
\end{tabular}

Taenia taeniaformis infection was $5.3 \%$ in male cats and Opisthorchis sp infection was $1.9 \%$ in female cats (Table 2). Incidence rates of protozoa in cats were as Table 3. Protozoan infections in female cats were higher than those in male cats. Infection rates of Isospora felis, $T$. gondii and Sarcocystis sp were 11.1, 13.0 and 3.7\%, respectively. Those of Isospora felis and T. gondii were $5.3 \%$, respectively (Table 3). In serological diagnosis of Toxoplasma gondii in wild cats in Suwon area by ELISA, positive rate was $9.8 \%$. Those of male female were $5.3 \%$ and $13.0 \%$, respectively (Table 4 ).

\section{Discussion}

Ninety eight cats of Suwon area investigated zoototic parasites, Nine kinds of parasites came out. Toxocara cati was the biggest rate (34 samples), the second rate was a Toxoplasma gondii ( 9 samples), the third rate was an Isospora felis (8 samples). Toxocara cati in male was higher than that in female, but those other parasites in female were generally higher than those in male. Parasites of cats and various wild felidae are widely distributed in the Korea. Transmission to humans is possible and particularly dangerous for children Cats need to be prevented from ingesting soil or anything contaminated with infective eggs. Because of the zoonotic potential of round worms, and to protect cats, all sources of infection should be reduced and keep the environment clean, control rodent populations. The seroprevalences of toxoplasmosis were from 0.79 to $13.2 \%$ by ELISA and/or PCR in the humans [3, 5, 6, $11,16,19,20,22]$. Those were from 8.1 to $47.2 \%$ by ELISA and/or PCR in the stray cats [8, 13-15]. Those were from 8.1 to $47.2 \%$ by Latex agglutination test in the aborted pigs [9]. The seroprevalences of toxocariasis were from 67.0 to $68.0 \%$ by ELISA in the people [10, 12]. Min [18] reviewed that the prevalence of Toxocara cati was $7.7 \%$, Ancylostoma tubaeforme $3.1 \%, C$. sinensis $1.9 \%$, P. westermani $1.4 \%$, M. yokogawai $1.2 \%$ and Spirometra sp. $0.7 \%$ in the cats. Min [17] reported that the prevalence of Capillaria Hepatica was $38 \%$ among house rat in Seoul. The incidence rates of this experiment were same as the previous reports. The stray cats would spread the eggs or oocysts of parasites on the play-ground of children, so that we must control the stray cats and clean the play-ground.

\section{Aknowledgments}

This work was supported by Korean Research Foundation Grant (KRF-2006-005-J02902).

\section{References}

1. Camargo ME, Ferreira AW, Mineo JR, Takiguti CK, Nakahara OS. Immunoglobulin G and immunoglobulin $\mathrm{M}$ enzyme-linked immunosorbent assays and defined toxoplasmosis serological patterns. Infect Immun 1978, 21, 55-58.

2. Chai JY, Lin A, Shin EH, Oh MD, Han ET, Nan HW, Lee SH. Laboratory passage and characterization of an isolate of Toxoplasma gondii from an ocular patient in Korea. Korean J Parasitol 2003, 41, 147-154.

3. Choi WY. Diagnosis and epidemiology of toxoplasmosis in Korea. Kisaengchunghak Chapchi 1990, 28 (Suppl), 41-44.

4. Choi WY, Nam HW, Youn JH, Kim DJ, Kong Y, Kang SY, Cho SY. Detection of antibodies in serum and cerebrospinal fluid to Toxoplasma gondii by indirect latex agglutination test and enzyme-linked immunosorbent assay. Kisaengchunghak Chapchi 1992, 30, 83-90.

5. Choi WY, Nam HW, Youn JH, Kim WS, Kim WK. Toxoplasma antibody titers by indirect latex agglutination test in patients of Kangnam St. Mary's Hospital and Cheju Medical Center. Kisaengchunghak Chapchi 1989, 27, 171-175.

6. Hong SJ, Chong CK, Lee K, Kim TS, Hong YP, Ahn HJ, Kim HY, Ko AR, Kim YJ, Nam HW. Maintained seroprevalence of toxoplasmosis among the residents of Jeju island, Korea. Korean J Parasitol 2011, 
49, 309-311.

7. Huh S, Sohn WM, Chai JY. Intestinal parasites of cats purchased in Seoul. Korean J Parasitol 1993, 31, 371373.

8. Kim HY, Kim YA, Kang S, Lee HS, Rhie HG, Ahn HJ, Nam HW, Lee SE. Prevalence of Toxoplasma gondii in stray cats of Gyeonggi-do, Korea. Korean $\mathrm{J}$ Parasitol 2008, 46, 199-201.

9. Kim JH, Kang KI, Kang WC, Sohn HJ, Jean YH, Park BK, Kim Y, Kim DY. Porcine abortion outbreak associated with Toxoplasma gondii in Jeju Island, Korea. J Vet Sci 2009, 10, 147-151.

10. Kim YH, Huh S, Chung YB. Seroprevalence of toxocariasis among healthy people with eosinophilia. Korean J Parasitol 2008, 46, 29-32.

11. Kook J, Lee HJ, Kim BI, Yun CK, Guk SM, Seo M, Park YK, Hong ST, Chai JY. Toxoplasma gondii antibody titers in sera of children admitted to the Seoul National University Children's Hospital. Korean J Parasitol 1999, 37, 27-32.

12. Kwon NH, Oh MJ, Lee SP, Lee BJ, Choi DC. The prevalence and diagnostic value of toxocariasis in unknown eosinophilia. Ann Hematol 2006, 85, 233238.

13. Lee JY, Lee SE, Lee EG, Song KH. Nested PCRbased detection of Toxoplasma gondii in German shepherd dogs and stray cats in South Korea. Res Vet Sci 2008, 85, 125-127.

14. Lee SE, Kim JY, Kim YA, Cho SH, Ahn HJ, Woo HM, Lee WJ, Nam HW. Prevalence of Toxoplasma gondii infection in stray and household cats in regions of Seoul, Korea. Korean J Parasitol 2010, 48, 267-270.

15. Lee SE, Kim NH, Chae HS, Cho SH, Nam HW, Lee WJ, Kim SH, Lee JH. Prevalence of Toxoplasma gondii infection in feral cats in Seoul, Korea. J Parasitol 2011, 97, 153-155.

16. Lee YH, Noh HJ, Hwang OS, Lee SK, Shin DW. Seroepidemiological study of Toxoplasma gondii infection in the rural area Okcheon-gun, Korea. Korean J Parasitol 2000, 38, 251-256.

17. Min HK. [Prevalence of Capillaria hepatica among house rat in Seoul]. Kisaengchunghak Chapchi 1979, 17, 93-97.

18. Min HK. [An epidemiological study on zoonoses in Korea]. Kisaengchunghak Chapchi 1981, 19, 60-75.

19. Ryu JS, Min DY, Ahn MH, Choi HG, Rho SC, Shin YJ, Choi B, Joo HD. Toxoplasma antibody titers by ELISA and indirect latex agglutination test in pregnant women. Korean J Parasitol 1996, 34, 233-238.

20. Song KJ, Shin JC, Shin HJ, Nam HW. Seroprevalence of toxoplasmosis in Korean pregnant women. Korean J Parasitol 2005, 43, 69-71.

21. Yamamoto YI, Hoshino-Shimizu S, Camargo ME. A novel IgM-indirect hemagglutination test for the serodiagnosis of acute toxoplasmosis. J Clin Lab Anal 1991, 5, 127-132.

22. Yang HJ, Jin KN, Park YK, Hong SC, Bae JM, Lee SH, Choi HS, Hwang HS, Chung YB, Lee NS, Nam HW. Seroprevalence of toxoplasmosis in the residents of Cheju island, Korea. Korean J Parasitol 2000, 38, 91-93. 